\title{
Psychological Traits as Predictors of Science Achievement for Students Participated in TIMSS 2015
}

\author{
Yoon Fah LAY ${ }^{1, *}$, Khar Thoe NG \\ ${ }^{1}$ Faculty of Psychology and Education, Universiti Malaysia Sabah, 88400 Kota Kinabalu, Sabah, Malaysia \\ ${ }^{2}$ Research \& Development Division, SEAMEO RECSAM, 11700 Gelugor, Penang, Malaysia
}

Received June 29, 2020; Revised October 12, 2020; Accepted October 24, 2020

\section{Cite This Paper in the following Citation Styles}

(a): [1] Yoon Fah LAY, Khar Thoe NG, "Psychological Traits as Predictors of Science Achievement for Students Participated in TIMSS 2015," Universal Journal of Educational Research, Vol. 8, No. 11B, pp. 5749 - 5759, 2020. DOI: 10.13189/ujer.2020.082209.

(b): Yoon Fah LAY, Khar Thoe NG (2020). Psychological Traits as Predictors of Science Achievement for Students Participated in TIMSS 2015. Universal Journal of Educational Research, 8(11B), 5749 - 5759. DOI: 10.13189/ujer.2020.082209.

Copyright $\bigcirc 2020$ by authors, all rights reserved. Authors agree that this article remains permanently open access under the terms of the Creative Commons Attribution License 4.0 International License

\begin{abstract}
Previous researches found various psychological traits (e.g., emphasis of school on academic success, job satisfaction and challenges faced by teachers as well as sense of belonging among students) could have affected science achievement of students. This study examined the predictive effects of school climate on science achievement among Southeast Asian Grade 8 students participated in Trends in International Mathematics and Science Study (TIMSS) 2015. In this research, school principals' and science teachers' reports of school emphasis on academic success, psychological traits such as science teachers' job satisfaction and challenges faced as well as students' sense of belonging towards school were analyzed using International Database (IDB) Analyzer. Data were obtained from 9,726 Malaysian students, 6,116 Singaporean students, and 6,482 Thai students who participated in TIMSS 2015. The analysis revealed that school emphasis on academic success as reported by school principals and science teachers in Malaysia and Thailand were significantly associated with and contributed to students' science achievement. The sense of school belonging of students from Malaysia and Singapore was also significantly associated with and contributed to students' science achievement. On the contrary, the scores of Thai female students for TIMSS 2015 were significantly higher than their male counterparts. Hence, school administrators should ensure that cognitive and socio-psychological aspects of the implementation of all activities are well taken care of throughout the years to ensure academic
\end{abstract}

success of students.

Keywords School Climate, IDB Analyzer, Psychological Traits, Science Achievement, TIMSS

\section{Introduction}

\subsection{Background and Overview}

Since 1995, the Trends in International Mathematics and Science Study (TIMSS) was implemented as an international comparative study by the International Association for the Evaluation of Educational Achievement (IEA). TIMSS was devised to assess quality of science and mathematics education in participating countries involving Grades 4 and 8 students as reported Martin, Mullis, Foy, and Stanco in 2012 [1]. Korea and Singapore were found to be the top science achievers for fourth grade, whereas Hong Kong SAR, Japan and Russia Federation were listed in the top five in the recent cycle of TIMSS study. Singapore was the top science achiever at Grade 8 while Chinese Taipei, Japan, Korea, and Slovenia were among the top five achievers. East Asian countries like Chinese Taipei, Hong Kong SAR, Japan, Korea, and Singapore were also among the top achievers in mathematics at Grade 4 and Grade 8.

It is undeniable that factors which might have contributed to the outstanding science performance in 
TIMSS are multi-faceted. Various such contributing factors which include cognitive, affective (i.e., attitude, interest and motivation), also the aspects of psycho/sociology have been researched extensively in the recent years especially among researchers and policy makers who wish to see the improvement in the quality of educational systems in their country such as Malaysia (see Ong and Gonzalez in 2012 [2]; Ong, Gonzalez, and Shanmugam in 2013 [3]).

The Malaysian government has placed much emphasis on benchmarking students' cognitive performance against international standards through participating in comparative study such as TIMSS by MOE in 2012 [4] from the early stage till the most recent years. Even though there are 11 countries in the Southeast Asian region, only three out of the eleven member countries, including Malaysia, Singapore, and Thailand, participated in TIMSS 2015. However, unlike their counterpart- Singapore, both Malaysia and Thailand were only ranked $24^{\text {th }}$ and $28^{\text {th }}$ in Grade 8 TIMSS 2015 science assessment. These two countries were also ranked $22^{\text {nd }}$ and $30^{\text {th }}$ in Grade 8 TIMSS 2015 mathematics assessment. Hence there is much to learn from the success of the neighboring country but this study will only focus on specific areas.

\subsection{Aim and Research Question}

The ultimate aim of this article is to analyze several psychological traits (including school emphasis on academic success as motivation factor, teacher's job satisfaction and perception on challenges faced as well as students' sense of belonging) as variables to predict the science achievement of students participating in TIMSS 2015.

The research question that underpinned this study was: Using the TIMSS 2015 data, how well do school emphasis on academic success, teacher job satisfaction, challenges facing teachers, and students' sense of school belonging predict students' science achievement in TIMSS 2015?"

\section{Literature Review}

This section review literature related to Research Objectives.

\subsection{Historical Overview of TIMSS Participation and Comparison of Performance}

Since 1995 Singapore participated in the TIMSS at Grade 4 and Grade 8 levels. However, in 1999, Malaysia participated in the program only at Grade 8 level and Thailand at both Grade 4 and Grade 8 levels. Table 1 summarizes the science and mathematics performances of these three SEAMEO member countries at Grade 8 level from TIMSS 1995 to TIMSS 2015.
Table 1. TIMSS (Grade 8) Science Scores for Malaysia, Singapore and Thailand (1995-2015)

\begin{tabular}{|c|c|c|c|c|}
\hline & \multicolumn{4}{|c|}{ TIMSS Science Scores of Grade 8 Students } \\
\hline Year & $\begin{array}{c}\text { No. of } \\
\text { Participating } \\
\text { Countries }\end{array}$ & Malaysia & Singapore & Thailand \\
\hline 1995 & 45 & - & 580 & - \\
\hline 1999 & 38 & 492 & 568 & 482 \\
\hline 2003 & 46 & 510 & 578 & - \\
\hline 2007 & 59 & 471 & 567 & 471 \\
\hline 2011 & 63 & 426 & 590 & 451 \\
\hline 2015 & 46 & 471 & 597 & 456 \\
\hline
\end{tabular}

\subsection{Relationship between Psychological Traits and Achievement in Science}

Through an extensive review of literature, Thapa, Cohen, Guffey, and Alessandro (2013) [5] found that climate of school correlates to academic achievement at different level of schooling such as elementary schools and middle schools. Actually, school climate is not only affected by the types or levels of schools, but also rural vs. urban, or whether the school consists of samples with diverse socio-economic backgrounds including lower-class, middle-class and upper-class culture. In other words, different culture may have different school climate and supported by different policies set by the respective countries. The ways students learn in Western culture as researched by Hebib and Zunic-Pavlovic [6], Suwalska (2018) [7] and Thapa, et al. [5] as well as Eastern cultures as reported by (Fraser and Goh (2003) [8] and Vadivel and Bhati (2017) [9] differ to some extent.

McEvoy and Welker (2000) [10] defined climate of school as consists of factors underlying various psychological traits such as beliefs, attitudes, norms affecting teaching practices of principals (e.g., if the principal's emphasis is on the importance of academic success, this will serve as strong motivating factor for students to study hard; if the emphasis is on achievement in co-curriculum activities, this could be the motivating factor for students to spend more time to be excel in co-curricular activities) and teachers (e.g., whether their attitudes are positive or negative in facing challenges in teaching with job satisfaction despite constraints faced), the academic achievement level as well as the operation of school. Meanwhile, a comprehensive literature review in this area was performed by Thapa, et al. [5] which focussed on 5 dimensions of school climates namely institutional environment, relationships, safety, school improvement as well as teaching and learning (e.g., if the principal's emphasis is on importance of academic success, various measures will be taken to improve school facilities such as laboratory, multimedia room and library so that students can study in better school environment with better sense of belonging) process.

Many past research studies of TIMSS showed that 
climate of school is connected positively to achievements of students as reported by Mullis, Martin, Gonzalez, and Chrostowski in 2004 [11]; Mullis, Martin, and Foyin 2008 [12]; Martin, Mullis, and Foy in 2008 [13]. Stewart in 2008 [14] also claimed that the sense of cohesion towards school is the strongest variable to predict students' achievements. In this case, a critical reader might be interested in knowing why the climate of school is a good predictor of students' achievement. Freiberg (1999) [15] stated school climate referred to a set of characteristics that will influence the behaviour of students e.g., the quality of interpersonal relations between teachers and students, the perceived school safety, expectations of student learning (e.g., if principal's emphasis is on the importance of academic success, this will be strong motivator for students to study harder), the degree to which stakeholders are involved in decision making.

School climate is a latent variable therefore it cannot be observed directly. The measure of school climate is based on how researchers define this latent variable. Different researchers define school climate differently. However, these definitions are not entirely distinct. They do have similarities. For instance, Adeogun and Olisaemeka (2011) [16] defined school climate as comprising six sections namely general relationships and the conditions of work, home-school relationship, learning environment, socio-physical environment (e.g., principal who think that academic success of students is of utmost importance, he/she will strive hard to improve the facility of the school to ensure quality teaching learning, safety/security discipline, teacher care as well as support to students. From a macroscopic point of view, we can notice that this framework is a bit different from our framework of this paper in a sense that the notion of school climate in our paper includes the emphasis on academic success as motivation factor for students to study hard. On the contrary, the components such as orderly and safe school, school discipline as well as safety and students bullied at school [that was researched earlier by Lay and $\mathrm{Ng}$ (2019) [17] of our framework are pretty similar to the other sections of Adeogun and Olisaemeka's (2011) [16] framework. Based on Johnson, Stevens, and Zwoch (2007) [18], generally school climate can be defined as the psychosocial context (e.g., factors that caused teachers to have job satisfaction with less perceived challenges and students to have better sense of belongings) in which teachers work and teach. The study performed by Adeogun and Olisameka (2011) [16] revealed that there was a significant as well as direct relationship among academic performance, climate of school and teachers' productivity. However, the perceptions of principals, teachers and students for school climate were quite diverse for certain sections such as the section of teachers care and support to students. In this case, the students perceived that the section of teachers care and support to students had the greatest influence on performance and productivity. Meanwhile, the teachers had an opposite perception and felt that this section had the least influence on performance and productivity. As a researcher we should always be alert of the numerous sources of perceptions as these will provide us with very different data.

\section{Materials and Methods}

This study involves quantitative analysis of secondary data from international large-scale assessments in education using technological tool named as International Database Analyzer (abbreviated as IDB Analyzer). It includes a built-in integrated file that is used as technical manual to assist the users. The installation of IEA IDB Analyzer requires the NET Framework version 4.0 or above. If the researcher has an intention to install the IDB Analyzer on a machine with Windows 8 or earlier version, this .NET Framework that is accessible from the website https://www.microsoft.com/en-us/download/details.aspx?i $\mathrm{d}=17851$ should be installed onto the computer system as reported in IEA [19]. IDB Analyser is chosen as a tool to analyse IEA data because it is special statistical software that produces weighted estimates, correct standard errors and correct achievement scores using plausible values as reported in NCES [20]. Data for the study were extracted from the TIMSS 2015 database (http://timssandpirls.bc.edu/timss2015/international-datab ase/). The assessment of TIMSS 2015 involved a total of 22,324 Grade 8 students from Malaysia $(N=9,726)$, Singapore $(N=6,116)$, Thailand $(N=6,482)$.

\subsection{Science Achievement}

Survey items involving two aspects or domains of science, i.e. content (in Biology, Chemistry, Earth Science, Physics) and cognitive (Knowing, Applying, Reasoning) are found in the science achievement scale of TIMSS 2015. An imputation methodology was used in TIMSS. These include plausible values, to report performance of student. Plausible values consist of an approach developed by Mislevy and Sheehan in 1987 and 1989 [21] [22] and based on the imputation theory of Rubin in 1987 [23]. These are random elements extracted from the set of scores (i.e., the draws from the marginal posterior of the latent distribution randomly used as a measure of achievement in science. The IEA's International Database (IDB) Analyzer for TIMSS is a plug-in for SPSS It was used to combine the five plausible values also for producing their average values and standard errors that are corrected.

\subsection{School Emphasis on Academic Success- Principals' Reports}

The School Emphasis on Academic Success Scale was developed to measure principals' views on school emphasis on academic success, hence serving as an important motivating factor for students to study hard. The scale was based on thirteen items (BCBG14A to 
BCBG14MJ). All items were rated on a 5-point Likert-type scale with the range from ' 1 ' (Very low) to ' 5 ' (Very high). For this scale, the respective Cronbach's alpha reliability coefficients were $.915, .928$, and .914 for Malaysia, Singapore, and Thailand.

\subsection{School Emphasis on Academic Success- Teachers' Reports}

The School Emphasis on Academic Success Scale was developed to measure science teachers' views on school emphasis on academic success, which also serve as an important motivating factor for students to study hard. The scale was based on fourteen items (BTBG06A to BTBG06O). All items were rated on a 5-point Likert-type scale, ranging from ' 1 ' (Very low) to ' 5 ' (Very high). The Cronbach's alpha reliability coefficients for the scale were $.896, .888$, and .899 for Malaysia, Singapore, and Thailand, respectively.

\subsection{Job Satisfaction of Teachers}

The TIMSS 2015 Teacher Job Satisfaction Scale addresses science teachers' job satisfaction that is an important psychological trait for teacher to perform well in their teaching that can enhance students' achievement. The scale was based on seven items (BTBG10A to BTBG10G). All items were rated on a 4-point Likert type scale with the range from ' 1 ' (Never or almost never) to '4' (Very often). The Cronbach's alpha reliability coefficients for the scale were $.922, .946$, and .910 for Malaysia, Singapore, and Thailand, respectively.

\subsection{The Challenges Faced by Teachers}

The Challenges Facing Teachers Scale investigates science teachers' responses concerning their perceived challenges conditions in science teaching, another psychological trait that could either obstruct or improve the motivation of teacher to perform well in teaching. There were eight items in the scale (BTBG11A to BTBG11H). All items were rated from ' 1 ' (Disagree a lot) to '4' (Agree a lot), that is a 4-point Likert Scale method. The Cronbach's alpha reliability coefficients for the scale were .620 and .733 for Malaysia and Thailand, respectively.

\subsection{The Sense of School Belonging of Students}

The Students' Sense of School Belonging Scale investigates students' sense of school belonging, also another important psychological trait that could affect students' self-efficacy and motivation to study in their school learning environment. The scale was based on seven items (BSBG15A to BSBG15G). All items were rated on a 4-point Likert type scale with the range from ' 1 ' (Disagree a lot) to '4' (Agree a lot). The Cronbach's alpha reliability coefficients for the scale were $.793, .858$, and .757 for Malaysia, Singapore, and Thailand, respectively.

Apart from these measures, control variable such as student demographic characteristic for example, gender (dummy coded as $0=$ 'female', $1=$ 'male') was also included in the study.

\section{Data Analysis and Discussion}

This section discusses the results of the study with in-depth elaboration based on findings.

Based on the average scale scores as listed in Table 2, Malaysian school principals and science teachers reported that their schools had given the most emphasis on academic success as compared to their counterparts in Singapore and Thailand. Among the three countries compared, Malaysia showed the highest mean scores for both the principals and teachers may be due to the reason that Malaysia just launched the 10 years' Education Blueprint [4] and much emphasis was given by Malaysian government to improve the educational system including training for teachers and principals. Moreover, the country did not score well in TIMSS over the past 10 years and realize the need to much investments were made by the government recently hoping that Malaysia will resume their academic standing in TIMSS as shown in the earlier years when the country was once emplaced in middle third of benchmarking.

In terms of teacher job satisfaction, Thai science teachers were the most satisfied whereas Singaporean science teachers were the least satisfied. Thai science teachers were facing fewer challenges in their science teaching as compared to Malaysian counterparts. Thai students had the highest sense of school belonging whereas Singaporean students had the lowest sense of school belonging. Thailand is quite popular with the country's culture and tradition of which much is influenced by Buddhist teachings and their respect towards their King that promote tolerance and respect. With proper values cultivated from young, Thai people develop self-belief, self-satisfaction and internal motivation factors that have relationships with spiritual world also more important than external motivation factors that are related to material world. Due to the subservient nature (e.g., to practise wearing masks and social distancing during COVID-19 pandemic) of most of them, Thailand is one of the exemplary Southeast Asian countries that overcome the pandemic problem with the most current total case of 3,351 and the lowest (comparing with Malaysia and Singapore) death tolls of $0.8 / 1$ million population. It is generally believed that Thais respect in hierarchical relationship, in which 'there is always a person who is greater or more superior to the other' is the belief of most of them. The living and learning culture in Thailand may have promoted strong sense of belongings and obedient attitudes among 
Thai people. Hence, they show a great value on courtesy such as politeness and respect. It is also not surprising that Thai science teachers were the most satisfied in their job, face fewer challenges in science teaching and students had the highest sense of school belonging.

Table 2. The Weighted Descriptive Statistics with the Scores of Average Scale for School Emphasis on Academic Success (Principals' and Teachers' Reports), Teacher Job Satisfaction, Challenges Faced by Teachers, and Students' Sense of School Belonging

\begin{tabular}{|c|c|c|c|c|c|c|c|}
\hline \multirow{2}{*}{$\begin{array}{l}\text { State-ment } \\
\text { Code }\end{array}$} & \multirow{2}{*}{ Statement } & \multicolumn{2}{|c|}{ Malaysia } & \multicolumn{2}{|c|}{ Singapore } & \multicolumn{2}{|c|}{ Thailand } \\
\hline & & $\mathbf{M}$ & SD & $\mathbf{M}$ & SD & $\mathbf{M}$ & SD \\
\hline \multicolumn{8}{|c|}{ School Emphasis on Academic Success- Principals' Reports ${ }^{a}$} \\
\hline BCBG14A & $\begin{array}{l}\text { Teachers' understanding of the school's curricular } \\
\text { goals. }\end{array}$ & 1.57 & .530 & 1.80 & .531 & 1.92 & .594 \\
\hline BCBG14B & $\begin{array}{l}\text { Teachers' degree of success in implementing the } \\
\text { school's curriculum. }\end{array}$ & 1.81 & .597 & 2.10 & .594 & 2.28 & .595 \\
\hline BCBG14C & Teachers' expectations for student achievement. & 1.38 & .516 & 1.93 & .668 & 1.91 & .646 \\
\hline BCBG14D & $\begin{array}{l}\text { Teachers working together to improve student } \\
\text { achievement. }\end{array}$ & 1.46 & .531 & 1.77 & .658 & 1.95 & .650 \\
\hline BCBG14E & Teachers' ability to inspire students. & 1.75 & .579 & 2.23 & .613 & 2.11 & .624 \\
\hline BCBG14F & Parental involvement in school activities. & 2.82 & .854 & 3.04 & .868 & 2.60 & .894 \\
\hline BCBG14G & $\begin{array}{l}\text { Parental commitment to ensure that students are ready } \\
\text { to learn. }\end{array}$ & 2.62 & .865 & 2.59 & .765 & 2.66 & .928 \\
\hline BCBG14H & Parental expectations for student achievement. & 1.72 & .768 & 2.13 & .743 & 1.90 & .779 \\
\hline BCBG14I & $\begin{array}{l}\text { Parental support for the school to maintain high } \\
\text { academic standards. }\end{array}$ & 2.39 & .877 & 2.50 & .785 & 2.63 & .843 \\
\hline BCBG14J & $\begin{array}{l}\text { Parental pressure for the school to maintain high } \\
\text { academic standards. }\end{array}$ & 2.50 & .867 & 2.35 & .774 & 2.36 & .871 \\
\hline BCBG14K & Students' desire to do well in school. & 2.19 & .728 & 2.18 & .666 & 2.24 & .754 \\
\hline BCBG14L & Students' ability to reach school's academic goals. & 2.35 & .692 & 2.35 & .659 & 2.44 & .716 \\
\hline BCBG14M & Students' respect for classmates who excel in school. & 2.11 & .686 & 2.01 & .616 & 2.25 & .687 \\
\hline & Average scale score & \multicolumn{2}{|c|}{$10.96(.12)$} & \multicolumn{2}{|c|}{$10.74(.00)$} & \multicolumn{2}{|c|}{$10.28(.14)$} \\
\hline \multicolumn{8}{|c|}{ School Emphasis on Academic Success- Teachers' Reports ${ }^{\text {a }}$} \\
\hline BTBG06A & $\begin{array}{l}\text { Teachers' understanding of the school's curricular } \\
\text { goals. }\end{array}$ & 1.80 & .583 & 1.97 & .553 & 1.96 & .590 \\
\hline BTBG06B & $\begin{array}{l}\text { Teachers' degree of success in implementing the } \\
\text { school's curriculum. }\end{array}$ & 1.96 & .568 & 2.17 & .598 & 2.24 & .603 \\
\hline BTBG06C & Teachers' expectations for student achievement. & 1.38 & .533 & 2.00 & .605 & 1.95 & .646 \\
\hline BTBG06D & $\begin{array}{l}\text { Teachers working together to improve student } \\
\text { achievement. }\end{array}$ & 1.52 & .567 & 1.94 & .658 & 1.97 & .601 \\
\hline BTBG06E & Teachers' ability to inspire students. & 1.74 & .572 & 2.19 & .613 & 2.14 & .610 \\
\hline BTBG06F & Parental involvement in school activities. & 2.73 & .760 & 2.91 & .921 & 2.67 & .845 \\
\hline BTBG06G & $\begin{array}{l}\text { Parental commitment to ensure that students are ready } \\
\text { to learn. }\end{array}$ & 2.65 & .788 & 2.82 & .848 & 2.73 & .866 \\
\hline BTBG06H & Parental expectations for student achievement. & 1.71 & .757 & 2.33 & .799 & 2.00 & .785 \\
\hline BTBG06I & $\begin{array}{l}\text { Parental support for the school to maintain high } \\
\text { academic standards. }\end{array}$ & 2.24 & .830 & 2.74 & .801 & 2.54 & .863 \\
\hline BTBG06J & $\begin{array}{l}\text { Parental pressure for the school to maintain high } \\
\text { academic standards. }\end{array}$ & 2.53 & .819 & 2.54 & .866 & 2.56 & .825 \\
\hline BTBG06K & Students' desire to do well in school. & 2.07 & .780 & 2.45 & .687 & 2.37 & .735 \\
\hline BTBG06L & Students' ability to reach school's academic goals. & 2.39 & .730 & 2.67 & .703 & 2.61 & .683 \\
\hline BTBG06M & Students' respect for classmates who excel in school. & 2.31 & .746 & 2.43 & .699 & 2.37 & .712 \\
\hline BTBG06O & $\begin{array}{l}\text { Collaboration between school leadership and } \\
\text { teachers to plan instruction. }\end{array}$ & 1.71 & .633 & 2.42 & .789 & 1.96 & .699 \\
\hline & Average scale score & \multicolumn{2}{|c|}{$11.06(.12)$} & \multicolumn{2}{|c|}{$10.25(.08)$} & \multicolumn{2}{|c|}{$10.30(.12)$} \\
\hline
\end{tabular}


Table 2. Continuous

\begin{tabular}{|c|c|c|c|c|c|c|c|}
\hline \multicolumn{8}{|c|}{ Teacher Job Satisfaction ${ }^{\mathrm{c}}$} \\
\hline BTBG10A & I am content with my profession as a teacher. & 1.47 & .602 & 1.79 & .696 & 1.31 & .531 \\
\hline BTBG10B & I am satisfied with being a teacher at this school. & 1.65 & .644 & 1.95 & .750 & 1.44 & .638 \\
\hline BTBG10C & I find my work full of meaning and purpose. & 1.40 & .564 & 1.76 & .650 & 1.47 & .598 \\
\hline BTBG10D & I am enthusiastic about my job. & 1.41 & .548 & 1.80 & .692 & 1.46 & .558 \\
\hline BTBG10E & My work inspires me. & 1.49 & .603 & 1.88 & .730 & 1.46 & .603 \\
\hline BTBG10F & I am proud of the work I do. & 1.35 & .551 & 1.75 & 679 & 1.29 & .524 \\
\hline BTBG10G & I am going to continue teaching for as long as I can. & 1.35 & .562 & 1.91 & .774 & 1.33 & .616 \\
\hline \multicolumn{2}{|r|}{ Average scale score } & \multicolumn{2}{|c|}{$10.46(.15)$} & \multicolumn{2}{|c|}{$9.30(.13)$} & \multicolumn{2}{|c|}{$10.73(.15)$} \\
\hline \multicolumn{8}{|c|}{ Challenges Facing Teachers $^{\mathrm{d}}$} \\
\hline BTBG11A & There are too many students in the classes. & 2.03 & .919 & - & - & 2.25 & 1.10 \\
\hline BTBG11B & I have too much material to cover in class. & 2.42 & .617 & - & - & 1.95 & .860 \\
\hline BTBG11C & I have too many teaching hours. & 2.43 & .740 & - & - & 2.55 & .847 \\
\hline BTBG11D & I need more time to prepare for class. & 1.95 & .707 & - & - & 1.89 & .765 \\
\hline BTBG11E & I need more time to assist individual students. & 1.63 & 627 & - & - & 1.62 & .656 \\
\hline BTBG11F & I feel too much pressure from parents. & 2.96 & 619 & - & - & 2.97 & .818 \\
\hline BTBG11G & $\begin{array}{l}\text { I have difficulty keeping up with all the changes to } \\
\text { the curriculum. }\end{array}$ & 2.54 & .776 & - & - & 2.70 & .941 \\
\hline BTBG11H & I have too many administrative tasks. & 2.23 & .796 & - & - & 2.46 & .919 \\
\hline & Average scale score & \multicolumn{2}{|c|}{$9.57(.10)$} & \multicolumn{2}{|c|}{ - } & \multicolumn{2}{|c|}{$9.67(.16)$} \\
\hline \multicolumn{8}{|c|}{ Students' Sense of School Belonging ${ }^{c}$} \\
\hline BSBG15A & I like being in school. & 1.64 & .611 & 1.84 & .739 & 1.61 & .627 \\
\hline BSBG15B & I feel safe when I am at school. & 1.75 & 674 & 1.75 & .749 & 1.63 & .654 \\
\hline BSBG15C & I feel like I belong at this school. & 1.88 & .716 & 1.92 & .814 & 1.63 & .693 \\
\hline BSBG15D & I like to see my classmates at school. & 1.31 & .570 & 1.52 & 699 & 1.30 & .591 \\
\hline BSBG15E & Teachers at my school are fair to me. & 1.67 & .688 & 1.83 & .759 & 1.65 & .706 \\
\hline BSBG15F & I am proud to go to this school. & 1.50 & .637 & 1.84 & .808 & 1.31 & .553 \\
\hline BSBG15G & I learn a lot in school. & 1.37 & .582 & 1.56 & .653 & 1.35 & .556 \\
\hline & Average scale score & \multicolumn{2}{|c|}{$10.10(.05)$} & \multicolumn{2}{|c|}{$9.81(.03)$} & \multicolumn{2}{|c|}{$10.63(.05)$} \\
\hline
\end{tabular}

Note: 1= Disagree A Lot, 4= Agree A Lot; - No statistics are computed because there are no valid cases; Standard errors appear in parentheses.

Table 3. School Emphasis on Academic Success- Principals' Reports

\begin{tabular}{|c|c|c|c|c|c|c|c|c|}
\hline \multirow{2}{*}{ Country } & \multirow[b]{2}{*}{$N$} & \multicolumn{2}{|c|}{ Very High Emphasis } & \multicolumn{2}{|c|}{ High Emphasis } & \multicolumn{2}{|c|}{ Medium Emphasis } & \multirow{2}{*}{$\begin{array}{c}\text { Average } \\
\text { Scale Score }\end{array}$} \\
\hline & & $\%$ & Ave. Achv & $\%$ & Ave. Achv & $\%$ & Ave. Achv. & \\
\hline Malaysia & 9700 & $\begin{array}{l}10.00 \\
(2.11)\end{array}$ & $\begin{array}{l}523.83 \\
(12.14)\end{array}$ & $\begin{array}{l}65.17 \\
(3.62) \\
\end{array}$ & $\begin{array}{c}471.21 \\
(5.64)\end{array}$ & $\begin{array}{l}24.83 \\
(3.86)\end{array}$ & $\begin{array}{c}448.36 \\
(7.63)\end{array}$ & $\begin{array}{l}10.96 \\
(.12)\end{array}$ \\
\hline Singapore & 5945 & $\begin{array}{l}9.71 \\
(.00)\end{array}$ & $\begin{array}{c}661.09 \\
(8.73)\end{array}$ & $\begin{array}{r}64.27 \\
(.00)\end{array}$ & $\begin{array}{c}601.20 \\
(4.45)\end{array}$ & $\begin{array}{c}26.03 \\
(.00)\end{array}$ & $\begin{array}{c}561.84 \\
(6.08)\end{array}$ & $\begin{array}{l}10.74 \\
(.00)\end{array}$ \\
\hline Thailand & 6482 & $\begin{array}{c}4.57 \\
(1.54) \\
\end{array}$ & $\begin{array}{l}478.76 \\
(27.04)\end{array}$ & $\begin{array}{l}61.19 \\
(4.01) \\
\end{array}$ & $\begin{array}{r}467.21 \\
(5.44) \\
\end{array}$ & $\begin{array}{c}34.24 \\
(3.83)\end{array}$ & $\begin{array}{c}432.46 \\
(5.54)\end{array}$ & $\begin{array}{l}10.28 \\
(.14)\end{array}$ \\
\hline Average & & $\begin{array}{l}8.09 \\
(.87)\end{array}$ & $\begin{array}{l}554.56 \\
(10.30)\end{array}$ & $\begin{array}{c}63.54 \\
(1.80)\end{array}$ & $\begin{array}{c}513.21 \\
(3.01)\end{array}$ & $\begin{array}{l}28.36 \\
(1.81)\end{array}$ & $\begin{array}{c}480.89 \\
(3.74)\end{array}$ & $\begin{array}{l}10.66 \\
(.06)\end{array}$ \\
\hline
\end{tabular}

Note: 1. Standard errors in parentheses; 2. Ave. Achv.- abbreviation for 'Average Achievement' 
Tables 3 and 4 illustrate the Southeast Asian students' percentages according to principals' and teachers' reports on school emphasis on academic success respectively.

Tables 5 to 7 show the percentage of Southeast Asian students according to teacher job satisfaction, challenges facing teachers as well as students' sense of school belonging with their respective science achievement in average.

Table 4. School Emphasis on Academic Success- Teachers' Reports

\begin{tabular}{|c|c|c|c|c|c|c|c|c|}
\hline \multirow{2}{*}{ Country } & \multirow[b]{2}{*}{$N$} & \multicolumn{2}{|c|}{ Very High Emphasis } & \multicolumn{2}{|c|}{ High Emphasis } & \multicolumn{2}{|c|}{ Medium Emphasis } & \multirow{2}{*}{$\begin{array}{c}\text { Average } \\
\text { Scale Score }\end{array}$} \\
\hline & & $\%$ & Ave. Achv & $\%$ & Ave. Achv & $\%$ & Ave. Achv. & \\
\hline Malaysia & 9700 & $\begin{array}{c}8.71 \\
(1.90)\end{array}$ & $\begin{array}{l}480.53 \\
(16.90)\end{array}$ & $\begin{array}{l}67.67 \\
(3.29) \\
\end{array}$ & $\begin{array}{c}474.18 \\
(4.97)\end{array}$ & $\begin{array}{l}23.62 \\
(3.19)\end{array}$ & $\begin{array}{l}446.74 \\
(11.19)\end{array}$ & $\begin{array}{l}11.06 \\
(.12)\end{array}$ \\
\hline Singapore & 5945 & $\begin{array}{c}3.78 \\
(1.06) \\
\end{array}$ & $\begin{array}{l}628.90 \\
(18.11) \\
\end{array}$ & $\begin{array}{l}52.97 \\
(2.74) \\
\end{array}$ & $\begin{array}{c}620.68 \\
(4.65) \\
\end{array}$ & $\begin{array}{l}43.26 \\
(2.67) \\
\end{array}$ & $\begin{array}{c}564.40 \\
(5.69) \\
\end{array}$ & $\begin{array}{c}10.25 \\
(.08)\end{array}$ \\
\hline Thailand & 6482 & $\begin{array}{c}3.96 \\
(1.46)\end{array}$ & $\begin{array}{l}498.28 \\
(29.05)\end{array}$ & $\begin{array}{l}52.51 \\
(3.67)\end{array}$ & $\begin{array}{c}462.89 \\
(5.83)\end{array}$ & $\begin{array}{l}43.53 \\
(3.69)\end{array}$ & $\begin{array}{c}443.48 \\
(5.97)\end{array}$ & $\begin{array}{l}10.30 \\
(.12)\end{array}$ \\
\hline Average & & $\begin{array}{l}5.48 \\
(.87)\end{array}$ & $\begin{array}{l}535.90 \\
(12.73)\end{array}$ & $\begin{array}{l}55.71 \\
(1.88)\end{array}$ & $\begin{array}{c}519.25 \\
(2.99)\end{array}$ & $\begin{array}{l}36.80 \\
(1.85)\end{array}$ & $\begin{array}{c}484.87 \\
(4.63)\end{array}$ & $\begin{array}{c}10.54 \\
(.06)\end{array}$ \\
\hline
\end{tabular}

Note: 1. Standard errors in parentheses; 2. Ave. Achv.- abbreviation for 'Average Achievement'

Table 5. Teacher Job Satisfaction

\begin{tabular}{|c|c|c|c|c|c|c|c|c|}
\hline \multirow{2}{*}{ Country } & \multirow[b]{2}{*}{$N$} & \multicolumn{2}{|c|}{ Very Satisfied } & \multicolumn{2}{|c|}{ Satisfied } & \multicolumn{2}{|c|}{ Less than Satisfied } & \multirow{2}{*}{$\begin{array}{c}\text { Average } \\
\text { Scale Score }\end{array}$} \\
\hline & & $\%$ & Ave. Achv & $\%$ & Ave. Achv & $\%$ & Ave. Achv. & \\
\hline Malaysia & 9008 & $\begin{array}{l}60.71 \\
(3.98) \\
\end{array}$ & $\begin{array}{c}465.02 \\
(5.90)\end{array}$ & $\begin{array}{l}36.68 \\
(3.95)\end{array}$ & $\begin{array}{c}473.12 \\
(7.61)\end{array}$ & $\begin{array}{c}2.62 \\
(1.15)\end{array}$ & $\begin{array}{l}449.24 \\
(39.11)\end{array}$ & $\begin{array}{l}10.46 \\
(.15)\end{array}$ \\
\hline Singapore & 6116 & $\begin{array}{l}32.72 \\
(2.89)\end{array}$ & $\begin{array}{l}603.72 \\
(6.62)\end{array}$ & $\begin{array}{l}54.02 \\
(3.01)\end{array}$ & $\begin{array}{r}593.98 \\
(5.67)\end{array}$ & $\begin{array}{l}13.27 \\
(1.84)\end{array}$ & $\begin{array}{l}590.05 \\
(11.56)\end{array}$ & $\begin{array}{l}9.30 \\
(.13)\end{array}$ \\
\hline Thailand & 6453 & $\begin{array}{l}64.54 \\
(4.08)\end{array}$ & $\begin{array}{l}461.23 \\
(5.22)\end{array}$ & $\begin{array}{l}31.96 \\
(3.83)\end{array}$ & $\begin{array}{c}447.45 \\
6.81)\end{array}$ & $\begin{array}{c}3.49 \\
(1.43)\end{array}$ & $\begin{array}{l}443.31 \\
(21.91)\end{array}$ & $\begin{array}{l}10.73 \\
(.15)\end{array}$ \\
\hline Average & & $\begin{array}{l}52.66 \\
(2.13)\end{array}$ & $\begin{array}{l}509.99 \\
(3.43)\end{array}$ & $\begin{array}{l}40.89 \\
(2.09)\end{array}$ & $\begin{array}{r}504.85 \\
(3.89)\end{array}$ & $\begin{array}{l}6.46 \\
(.87)\end{array}$ & $\begin{array}{l}494.20 \\
(15.43)\end{array}$ & $\begin{array}{l}10.16 \\
(.08)\end{array}$ \\
\hline
\end{tabular}

Note: 1. Standard errors in parentheses; 2. Ave. Achv.- abbreviation for 'Average Achievement'

Table 6. Challenges Facing Teacher

\begin{tabular}{|c|c|c|c|c|c|c|c|c|}
\hline \multirow{2}{*}{ Country } & \multirow[b]{2}{*}{$N$} & \multicolumn{2}{|c|}{ Few Challenges } & \multicolumn{2}{|c|}{ Some Challenges } & \multicolumn{2}{|c|}{ Many Challenges } & \multirow{2}{*}{$\begin{array}{c}\text { Average } \\
\text { Scale Score }\end{array}$} \\
\hline & & $\%$ & Ave. Achv & $\%$ & Ave. Achv & $\%$ & Ave. Achv. & \\
\hline Malaysia & 8997 & $\begin{array}{l}32.03 \\
(3.62) \\
\end{array}$ & $\begin{array}{c}470.42 \\
(8.73) \\
\end{array}$ & $\begin{array}{l}66.10 \\
(3.75) \\
\end{array}$ & $\begin{array}{c}466.50 \\
(5.44) \\
\end{array}$ & $\begin{array}{l}1.87 \\
(.98) \\
\end{array}$ & $\begin{array}{c}533.77 \\
(5.78) \\
\end{array}$ & $\begin{array}{l}9.57 \\
(.10) \\
\end{array}$ \\
\hline Singapore & - & - & - & - & - & - & - & - \\
\hline Thailand & 6482 & $\begin{array}{l}34.66 \\
(3.71) \\
\end{array}$ & $\begin{array}{c}463.40 \\
(7.92) \\
\end{array}$ & $\begin{array}{l}60.30 \\
(3.99) \\
\end{array}$ & $\begin{array}{c}450.39 \\
(5.31) \\
\end{array}$ & $\begin{array}{c}5.04 \\
1.73) \\
\end{array}$ & $\begin{array}{l}469.10 \\
(17.77) \\
\end{array}$ & $\begin{array}{l}9.67 \\
(.16) \\
\end{array}$ \\
\hline Average & & $\begin{array}{l}33.35 \\
(2.59)\end{array}$ & $\begin{array}{c}466.91 \\
(5.89)\end{array}$ & $\begin{array}{l}63.20 \\
(2.74) \\
\end{array}$ & $\begin{array}{c}458.44 \\
(3.80)\end{array}$ & $\begin{array}{c}3.45 \\
(1.00) \\
\end{array}$ & $\begin{array}{c}501.44 \\
(9.34)\end{array}$ & $\begin{array}{l}9.62 \\
(.09)\end{array}$ \\
\hline
\end{tabular}

Note: 1. Standard errors in parentheses; 2. Ave. Achv.- abbreviation for 'Average Achievement'; - No statistics are computed because there are no valid cases;

Table 7. Students' Sense of School Belonging

\begin{tabular}{|c|c|c|c|c|c|c|c|c|}
\hline \multirow[t]{2}{*}{ Country } & \multirow[b]{2}{*}{$N$} & \multicolumn{2}{|c|}{$\begin{array}{c}\text { High Sense of School } \\
\text { Belonging }\end{array}$} & \multicolumn{2}{|c|}{$\begin{array}{c}\text { Sense of School } \\
\text { Belonging } \\
\end{array}$} & \multicolumn{2}{|c|}{$\begin{array}{c}\text { Little Sense of School } \\
\text { Belonging }\end{array}$} & \multirow{2}{*}{$\begin{array}{c}\text { Average } \\
\text { Scale Score }\end{array}$} \\
\hline & & $\%$ & Ave. Achv & $\%$ & Ave. Achv & $\%$ & Ave. Achv. & \\
\hline Malaysia & 9695 & $\begin{array}{l}45.88 \\
(1.27) \\
\end{array}$ & $\begin{array}{l}481.75 \\
(4.27) \\
\end{array}$ & $\begin{array}{l}50.16 \\
(1.10) \\
\end{array}$ & $\begin{array}{l}468.33 \\
(4.54) \\
\end{array}$ & $\begin{array}{l}3.96 \\
(.51) \\
\end{array}$ & $\begin{array}{l}384.25 \\
(12.09) \\
\end{array}$ & $\begin{array}{l}10.10 \\
(.05) \\
\end{array}$ \\
\hline Singapore & 6090 & $\begin{array}{l}36.64 \\
(.70) \\
\end{array}$ & $\begin{array}{l}613.62 \\
(3.21)\end{array}$ & $\begin{array}{l}54.64 \\
(.70) \\
\end{array}$ & $\begin{array}{l}590.52 \\
(3.50)\end{array}$ & $\begin{array}{l}8.72 \\
(.43)\end{array}$ & $\begin{array}{l}564.01 \\
(6.37) \\
\end{array}$ & $\begin{array}{l}9.81 \\
(.03)\end{array}$ \\
\hline Thailand & 6451 & $\begin{array}{l}57.77 \\
(1.24) \\
\end{array}$ & $\begin{array}{l}455.97 \\
(4.16) \\
\end{array}$ & $\begin{array}{l}40.18 \\
(1.21) \\
\end{array}$ & $\begin{array}{l}457.69 \\
(5.07) \\
\end{array}$ & $\begin{array}{l}2.05 \\
(.20) \\
\end{array}$ & $\begin{array}{l}427.55 \\
(10.31)\end{array}$ & $\begin{array}{l}10.63 \\
(.05) \\
\end{array}$ \\
\hline Average & & $\begin{array}{c}46.76 \\
(.63) \\
\end{array}$ & $\begin{array}{l}517.11 \\
(2.26) \\
\end{array}$ & $\begin{array}{c}48.33 \\
(.59) \\
\end{array}$ & $\begin{array}{l}505.52 \\
(2.55) \\
\end{array}$ & $\begin{array}{l}4.91 \\
(.23) \\
\end{array}$ & $\begin{array}{l}458.61 \\
(5.71) \\
\end{array}$ & $\begin{array}{l}10.18 \\
(.03) \\
\end{array}$ \\
\hline
\end{tabular}

Note: 1 . Standard errors in parentheses; 2. Ave. Achv.- abbreviation for 'Average Achievement' 
Correlation and multiple regression analyses were carried out simultaneously and separately for each education system. This was implemented to examine if the school climates were the factors to predict their science achievement (as elaborated in Table 7 as well as Table 8).

The results in Table 8 indicated that there was significant association between school emphasis on academic success with science achievement as reported by school principals in Malaysia, Singapore, and Thailand $(r=.24$ for Malaysia; $r=.35$ for Singapore, $r=.24$ for Thailand). For this aspect, there was also significant association between school emphasis on academic success with science achievement as reported by science teachers in Malaysia and Thailand $(r$ $=.14$ for Malaysia; $r=.17$ for Thailand). There was significant association between Malaysian and Singaporean students' sense of school belonging and their science achievement ( $r=.15$ for Malaysia; $r=.18$ for Singapore).

Table 8. Correlations between School Emphasis on Academic Success (Principals' Reports and Teachers' Reports), Job Satisfaction of Teachers, Challenges Faced by Teachers, Sense of School Belonging of Students with Science Achievement

\begin{tabular}{|c|c|c|c|c|c|c|c|c|c|c|c|c|}
\hline \multicolumn{13}{|c|}{ Malaysia } \\
\hline & \multicolumn{2}{|c|}{ BCDGEAS } & \multicolumn{2}{|c|}{ BTDGEAS } & \multicolumn{2}{|c|}{ BTDGTIS } & \multicolumn{2}{|c|}{ BTDGCFT } & \multicolumn{2}{|c|}{ BSBGSSB } & \multicolumn{2}{|c|}{ Science } \\
\hline & $r$ & $S E$ & $r$ & $S E$ & $r$ & $S E$ & $r$ & $S E$ & $r$ & $S E$ & $r$ & $S E$ \\
\hline BCDGEAS & 1.00 & .00 & - & - & - & - & - & - & - & - & $.24 *$ & .05 \\
\hline BTDGEAS & & & 1.00 & .00 & $.41^{*}$ & .05 & .05 & .07 & - & - & $.14^{*}$ & .05 \\
\hline BTDGTIS & & & & & 1.00 & .00 & .04 & .07 & - & - & -.02 & .06 \\
\hline BTDGCFT & & & & & & & 1.00 & .00 & - & - & .04 & .04 \\
\hline BSBGSSB & & & & & & & & & 1.00 & .00 & $.15^{*}$ & .03 \\
\hline Science & & & & & & & & & & & 1.00 & .00 \\
\hline
\end{tabular}

\begin{tabular}{|c|c|c|c|c|c|c|c|c|c|c|c|c|}
\hline \multicolumn{13}{|c|}{ Singapore } \\
\hline & \multicolumn{2}{|c|}{ BCDGEAS } & \multicolumn{2}{|c|}{ BTDGEAS } & \multicolumn{2}{|c|}{ BTDGTIS } & \multicolumn{2}{|c|}{ BTDGCFT } & \multicolumn{2}{|c|}{ BSBGSSB } & \multicolumn{2}{|c|}{ Science } \\
\hline & $r$ & $S E$ & $r$ & $S E$ & $r$ & $S E$ & $r$ & $S E$ & $r$ & $S E$ & $r$ & $S E$ \\
\hline BCDGEAS & 1.00 & .00 & - & - & - & - & - & - & - & - & $.35^{*}$ & .04 \\
\hline BTDGEAS & & & 1.00 & .00 & - & - & - & - & - & - & - & - \\
\hline BTDGTIS & & & & & 1.00 & .00 & - & - & - & - & - & - \\
\hline BTDGCFT & & & & & & & 1.00 & .00 & - & - & - & - \\
\hline BSBGSSB & & & & & & & & & 1.00 & .00 & $.18^{*}$ & .02 \\
\hline Science & & & & & & & & & & & 1.00 & .00 \\
\hline
\end{tabular}

\begin{tabular}{|c|c|c|c|c|c|c|c|c|c|c|c|c|}
\hline \multicolumn{13}{|c|}{ Thailand } \\
\hline & \multicolumn{2}{|c|}{ BCDGEAS } & \multicolumn{2}{|c|}{ BTDGEAS } & \multicolumn{2}{|c|}{ BTDGTIS } & \multicolumn{2}{|c|}{ BTDGCFT } & \multicolumn{2}{|c|}{ BSBGSSB } & \multicolumn{2}{|c|}{ Science } \\
\hline & $r$ & $S E$ & $r$ & $S E$ & $r$ & $S E$ & $r$ & $S E$ & $r$ & $S E$ & $r$ & $S E$ \\
\hline BCDGEAS & 1.00 & .00 & - & - & - & - & - & - & - & - & $.24^{*}$ & .05 \\
\hline BTDGEAS & & & 1.00 & .00 & $.39^{*}$ & .06 & .01 & .09 & - & - & $.17 *$ & .06 \\
\hline BTDGTIS & & & & & 1.00 & .00 & .09 & .06 & - & - & .08 & .05 \\
\hline BTDGCFT & & & & & & & 1.00 & .00 & - & - & .04 & .06 \\
\hline BSBGSSB & & & & & & & & & 1.00 & .00 & .02 & .02 \\
\hline Science & & & & & & & & & & & 1.00 & .00 \\
\hline
\end{tabular}

Note: ${ }^{*} p<.05$; BCDGEAS - School Emphasis on Academic Success (Principals' Reports); BTDGEAS - School Emphasis on Academic Success (Teachers' Reports); BTDGTIS - Teacher Job Satisfaction; BTDGCFT - Challenges Faced by Teachers; BSBGSSB - Sense of School Belonging; of Students Science - Science Achievement. 
Table 9. School Emphasis on Academic Success (Principals' Reports) in Predicting Students'

\begin{tabular}{|c|c|c|c|c|c|c|}
\hline & \multicolumn{2}{|c|}{ Malaysia } & \multicolumn{2}{|c|}{ Singapore } & \multicolumn{2}{|c|}{ Thailand } \\
\hline & $\beta$ & $S E$ & $\beta$ & $S E$ & $\beta$ & $S E$ \\
\hline Constant & $315.51^{*}$ & 33.78 & $411.75^{*}$ & 20.71 & 340.04 & 21.34 \\
\hline BCDGEAS & $14.17^{*}$ & 3.13 & $17.23^{*}$ & 1.86 & $14.17^{*}$ & 2.18 \\
\hline Adjusted $R^{2}$ & \multicolumn{2}{|c|}{.06} & .12 & & .06 & \\
\hline
\end{tabular}

Note: ${ }^{*} p<.05$; BCDGEAS-School Emphasis on Academic Success (Principals' Reports)

Table 10. School Emphasis on Academic Success (Teachers' Reports) in Predicting Students' Science Achievement

\begin{tabular}{ccccccc}
\hline & \multicolumn{2}{c}{ Malaysia } & \multicolumn{2}{c}{ Singapore } & \multicolumn{2}{c}{ Thailand } \\
\cline { 2 - 7 } & $\beta$ & $S E$ & $\beta$ & $S E$ & $\beta$ & $S E$ \\
\hline Constant & $383.43^{*}$ & 49.16 & $350.38^{*}$ & 39.71 & $366.91^{*}$ & 31.60 \\
BTDGEAS & $10.41^{*}$ & 3.42 & $8.25^{*}$ & 2.92 & $9.33^{*}$ & 2.25 \\
BTDGTJS & -5.25 & 3.99 & .68 & 2.31 & -2.28 & 2.30 \\
BTDGCFT & 2.56 & 3.23 & 1.39 & 2.69 & 1.97 & 2.10 \\
\hline Adjusted $R^{2}$ & & .03 & .03 & & .03 &
\end{tabular}

Note: ${ }^{*} p<.05$; BTDGEAS-School Emphasis on Academic Success (Teachers' Reports); BTDGTJS - Teacher Job Satisfaction; BTDGCFT Challenges Facing Teachers

Table 11. Grade 8 Students' Sense of School Belonging in Predicting Their Science Achievement

\begin{tabular}{|c|c|c|c|c|c|c|}
\hline & \multicolumn{2}{|c|}{ Malaysia } & \multicolumn{2}{|c|}{ Singapore } & \multicolumn{2}{|c|}{ Thailand } \\
\hline & $\beta$ & $S E$ & $\beta$ & $S E$ & $\beta$ & $S E$ \\
\hline Constant & $390.11^{*}$ & 20.10 & $515.50^{*}$ & 9.42 & $458.60^{*}$ & 12.52 \\
\hline Gender & -5.86 & 3.16 & 1.30 & 3.59 & -19.12 & 4.83 \\
\hline BSBGSSB & $8.32^{*}$ & 1.90 & $8.21^{*}$ & .79 & .59 & 1.03 \\
\hline Adjusted $R^{2}$ & \multicolumn{2}{|c|}{.02} & .03 & & .01 & \\
\hline
\end{tabular}

Note: ${ }^{*} p .05$; BSBGSSB- Students Sense of School Belonging (Students' Reports)

Based on Table 9, the significant $\beta$ values of school emphasis on academic success as reported by Malaysian, Singaporean, and Thai school principals $(14.17,17.23$, and 11.27, respectively) contributed significantly to their students' science achievement.

Based on Table 10, the significant $\beta$ values of school emphasis on academic success as reported by Malaysian, Singaporean and Thai science teachers $(10.41,8.25$, and 9.33, respectively) contributed significantly to their students' science achievement.

Based on Table 11, the significant $\beta$ values of Malaysian and Singaporean students' sense of school belonging (8.32 and 8.21, respectively) contributed significantly to the science achievement of these students. On the other hand, there was higher significance of scores for TIMSS 2015 science assessment among Thai female students as compared to their male counterparts.

\section{Conclusions}

\section{Significance and Implications}

School emphasis on academic success as reported by
Malaysian, Singaporean, and Thai school principals and science teachers contributed significantly to their students' science achievement. In fact, the delivery of regular motivational remarks (such as words of praise or encouragement and vote of thanks or appreciation) are important psychological traits not only to improve work performance but academic achievement as reflected in this study. Hence, the administrators in the respective schools should ensure that cognitive and socio-psychological aspects of the implementation of all activities are well taken care of throughout the years. These include the understanding of the curricular goals, the success rate in the implementation of school's curriculum as well as the expectation and ability of teachers to work collaboratively towards improving student achievement. Of course, students should be motivated to do well. In fact, these students are expected to be capable of achieving the school's goals for academic work supported by actively involving their parents who have high expectation and with commitment in ensuring that students are prepared to learn.

It is believed that governmental policies strongly affect the movement in any systems; in this case, it refers to educational system such as the Educational Blueprint of Malaysia as aforementioned. Probably, government should 
also revise educational policy more often to tackle the issues of teachers' job satisfaction that is also one of the significant predictors of students' achievement in this study.

Malaysian and Singaporean students' sense of school belonging also contributed significantly to their science achievement. However, although Thai female students scored significantly higher than their male counterparts on the TIMSS 2015 science assessment, gender did not seem to be an important issue and did not predict academic achievement in Malaysia and Singapore. Hence this is a good indication and these countries should continue with the practice of the United Nation's educational policy of 'Education for all', Irrespective of the socio-cultural backgrounds of all, students of both gender were or should be given the equal opportunity and attention to achieve academic excellence.

\section{Limitation and Suggestions for Future Studies}

This paper analyzes several psychological traits (including school emphasis on academic success, teacher's job satisfaction, challenges facing teachers as well as students' sense of belonging) as predictors of students' science achievement in TIMSS 2015, a cross-sectional survey based on secondary data obtained from IEA database using IDB analyzer. Hence, this weakness of 'relying on self-report surveys' is the limitation of the research design that leads to assumptions made regarding relationships between the constructs. Due to constraints faced also in terms of time and availability of data (e.g., there was missing data of 'Challenges facing teachers' in Singapore), only three ASEAN countries are selected for analysis as reported in this study.

Perhaps longitudinal study could be conducted with alternative hypotheses to explore the effect of the abovementioned psychological traits on other motivation factor as what was reported by Ng, Soon, and Fong (2010) [24]. Questionnaire such as 'Motivation towards STEM education or other latest trends of education' could be devised to identify constructs related to psychological factors that predict achievement.

Since school principals play important roles in contributing to students' science achievement in all three countries being studied, more studies on educational leadership should be conducted to examine how principals as main supporters or prime motivators could inspire students to learn better also to ensure continuous support is given in all schools. In addition, the gender difference finding as shown in samples from Thailand is worth exploring further in future research.

Learning culture is important for the healthy growth of learners. The study on human values as reported [25] and [26] is also important to showcase exemplary country like Thailand in which teachers showed good value of high job satisfaction and students have great sense of school belongings that are significant predictors of academic success.

\section{Acknowledgments}

The authors wish to acknowledge Universiti Malaysia Sabah special fund grant scheme (SDK0242-2020) for funding this research project.

\section{REFERENCES}

[1] M. O. Martin, I. V. Mullis, P. Foy, G. M. Stanco. TIMSS 2011 International Results in Science. 2012. Amsterdam, The Netherlands: International Association for the Evaluation of Educational Achievement.

[2] S.L. Ong, E.J. Gonzalez. TIMSS 2007: What can we learn? (Eds.). 2012. Penang: SEAMEO-RECSAM.

[3] S.L. Ong, E.J. Gonzalez, S.K.S. Shanmugam (Eds.). TIMSS 2011: What can we learn together in reaching greater heights? 2013. Penang: SEAMEO-RECSAM.

[4] MOE. Malaysia Education Blueprint 2013-2025. Preliminary Report-Executive Summary. September, 2012. Ministry of Education (MOE) Malaysia.

[5] A. Thapa, J. Cohen, S. Guffey, A.H.-D'Alessandro. A review of school climate research. Review of Educational Research. September 2013, Vol.83, No.3, pp.357-385. Retrieved August 20, 2020 from https://k12engagement.unl .edu/REVIEW\%20OF\%20EDUCATIONAL\%20RESEAR CH-2013-Thapa-357-85.pdf

[6] E. Hebib, V. Zunic-Pavlovic. School climate and school culture: A framework for creating school as a safe and stimulating environment for learning and development. Zbornik Institute za pedagoska istrazivanja. 50(1): 113-114. January 2018. Retrieved August 20, 2020 from https://www.researchgate.net/publication/325869639_Scho ol climate and school culture A framework for_creating _school_as_a_safe_and_stimulating_environment_for_lear ning_and_development

[7] A. Suwalska. Culture of teaching in Finnish schools in context of educational change. Polish Journal of Educational Studies. Vol. I (LXXI) 2018. Retrieved August 20, 2020 from

https://www.researchgate.net/publication/331229754_Cultu re_of_teaching_in_Finnish_schools_in_context_of_educati onal_change

[8] B.J. Fraser and S.C. Goh. Classroom learning environments. Classroom learning environments. In J.P. Keeves et al. (Eds). International Handbook of Educational Research in Asia-Pacific region. Springer International Handbooks of Education, Vol. 11, 2003, Springer, Dordrecht. Retrieved August 20, 2020 from https://link.springer.com/chapter/10. 1007/978-94-017-3368-7_32\#citeas

[9] V.S. Vadivel, I. Song, A. Bhati. Improving teaching and learning in Southeast Asian secondary schools with the use of culturally motivated web and mobile technology. March 2017. International Conference on Information Science and 
Applications. Retrieved August 20, 2020 from https://www.researchgate.net/publication/315317565_Impr oving_Teaching and_Learning_in_Southeast_Asian_Secon dary_Schools_with_the_Use_of_Culturally_Motivated_We b_and_Mobile_Technology

[10] A. McEvoy, R. Welker. Antisocial behavior, academic failure and school climate: a critical review. Journal of emotional and behavioural disorders, 8(3), 130-140, 2000.

[11] I.V., Mullis, M.O. Martin, E.J. Gonzalez, S.J. Chrostowski. TIMSS 2003 International Mathematics Report: Findings from IEA's Trends in International Mathematics and Science Study at the Fourth and Eighth Grades. TIMSS \& PIRLS International Study Center. Boston College, 140 Commonwealth Avenue, Chestnut Hill, MA 02467, 2004.

[12] I.V.S. Mullis, M.O. Martin, P. Foy. TIMSS 2007 International Mathematics Report: Findings from IEA's Trends in International Mathematics and Science Study at the Fourth and Eighth Grades. Chestnut Hill, MA: TIMSS \& PIRLS International Study Center, Boston College, 2008.

[13] M.O. Martin, I.V.S. Mullis, P. Foy. TIMSS 2007 International Science Report: Findings from IEA's Trends in International Mathematics and Science Study at the Fourth and Eighth Grades. 2008. Chestnut Hill, MA: TIMSS \& PIRLS International Study Center, Boston College.

[14] E.B. Stewart. School structural characteristics, student effort, peer associations and parental involvement. Education and Urban Society. 40(2), 179-204, 2008.

[15] H.J. Freiberg (Ed). School climate: Measuring, improving and sustaining healthy learning environments. Philadelphia: Falmer Press, 1999.

[16] A.A. Adeogun, U. Olisaemeka Blessing. Influence of school climate on Students' Achievement and Teachers' Productivity for sustainable development.US-China Education Review, 8(4), 552-557, 2001.

[17] Y.F. Lay, K.T. Ng (2019). The predictive effects of school safety on Southeast Asian Grade 8 students' science achievement in TIMSS2015. Jurnal Pendidikan IPA Indonesia. 8(3), 426-435, 2019. Retrieved August 20, 2020 from https://journal.unnes.ac.id/nju/index.php/jpii/article/viewFil e/18898/9603

[18] B. Johnson, J.J. Stevens, K. Zwoch. Teachers' perception of school climate: A validity study of scores from the revised school level environment questionnaire. Educational and
Psychological Measurement, 67(5), 833-844, 2007.

[19] IEA. Tools working with IEA data. International Association for the Evaluation of Educational Achievement (IEA). n.d. Retrieved April 7, 2020. Available: https://www.iea.nl/data-tools/tools\#spy-para-308

[20] NCES. Considerations for analysis of International activities program data. n.d. Retrieved April 7, 2020. Available: https://nces.ed.gov/training/datauser/IAPS 05/assets/IAPS 05_Transcript.pdf

[21] R.J. Mislevy, K.M. Sheehan. Marginal estimation procedures. In A. E. Beaton (Ed.), The NAEP 1983/84 Technical Report (NAEP Report 15-TR-20, pp. 121-211). 1987. Princeton, NJ: Educational Testing Service.

[22] R.J. Mislevy, K.M. Sheehan. Information matrices in latent-variable models. Journal of Educational and Behavioral Statistics, 14(4), 335-350, 1989.

[23] D.B. Rubin. Multiple imputation for nonresponse in surveys. New York: Wiley, 1987.

[24] K.T. Ng, S.T. Soon, S.F. Fong, S.F. Development of a questionnaire to evaluate students' perceived motivation towards science learning incorporating ICT tools. 2010. Retrieved August 11, 2020 from https://www.researchgate. net/profile/Khar_Ng/publication/316084831 Development of_a_Questionnaire_to_Evaluate_Students'_Perceived Motivation towards Science Learning Incorporating ICT Tool/links/58ef5549 a 6 fdccd5c46d73ae/Development-of-a -Questionnaire-to-Evaluate-Students-Perceived-Motivationtowards-Science-Learning-Incorporating-ICT-Tool.pdf

[25] K.T. Ng. Integration of human values in HVWSHE curriculum incorporating teaching strategies/approaches and assessment/evaluation techniques. In P.Pannen, Ng K.T., J. Ikhsan, D. Mustafa \& Herawati (Eds.). SEAMEO resource package: Human Values-based Water, Sanitation and Hygiene Education (HVWSHE). SEAMEO SEAMOLEC and UN-HABITAT. 2007. Retrieved August 11, 2020 from https://scholar.google.com/scholar?cluster $=6622390137260$ $114690 \&$ hl=en\&oi $=$ scholarr

[26] L. Toh, C.H. Yeap, K.T. Ng, F. Isma. Cross-curricular teaching incorporating human values: A collaborative research by reflective practitioners. Learning Science and Mathematics online journal. Volume 2, pp.9-31, 2007. Retrieved August 11, 2020 from http://scholar.google.com/ scholar?cluster $=7248508657243676708 \&$ hl $=$ en \&oi $=$ schola rr 